\title{
Téoros
}

Revue de recherche en tourisme

\section{Developing Coalitions in a Tourism-Based Economy: The New Orleans Joint Center for Tourism}

\section{Jane S. Brooks et Kenneth J. Lacho}

Volume 10, numéro 1, mars 1991

Tourisme et environnement

URI : https://id.erudit.org/iderudit/1079815ar

DOI : https://doi.org/10.7202/1079815ar

Aller au sommaire du numéro

Éditeur(s)

Université du Québec à Montréal

ISSN

0712-8657 (imprimé)

1923-2705 (numérique)

Découvrir la revue

Citer cet article

Brooks, J. S. \& Lacho, K. J. (1991). Developing Coalitions in a Tourism-Based Economy: The New Orleans Joint Center for Tourism. Téoros, 10(1), 21-42. https://doi.org/10.7202/1079815ar
Résumé de l'article

Le quartier du Vieux-Carré en Nouvelle-Orléans constitue une attraction exceptionnelle pour les touristes. Cependant, la croissance du volume touristique est telle que cela peut devenir dangereux pour sa survie. La création du " New Orleans Joint Center for Tourism " résulte de l'action de ceux qui veulent conserver le patrimoine historique du Vieux Carré. La mise en commun des ressources d'organismes divers reliés au tourisme démontre la volonté du milieu de contrôler la croissance de l'industrie touristique et, du même coup, de préserver l'héritage historique du Vieux Carré. Les problèmes que rencontrent le « New Orleans Joint Center for Tourism " pour atteindre ses objectifs relèvent, entre autres, d'un manque de ressources de la direction centrale et du peu d'implication du gouvernement municipal. 


\section{Developing Coalitions in a Tourism-Based Economy: The New Orleans Joint Center for Tourism}

\section{Summary}

The New Orleans Vieux Carre is an attraction to tourists, yet the growth of tourim may well be a threat to its very survival. The formation of the JCT and Cultural Treasures Groupreflects the efforts of people who are concerned about the preservation of the Vieux Carre as an intact historic neighborhood. The reaching out to tourism-related organizations reflects an attempt to work with these groups in developing a mechanism for controlling growth of the tourism industry, yet at the same time preserving an historic neighborhood. The problems of the JCT in achieving its goals are simply due to the lack of resources, central control, and perceived inattention by city government.

The difficulty of the JCT toprogress towards its objectives has resulted in a spinoff subgroup. This group is smaller, more compact, members have similar values, and belong to organizations directly related to the Vieux Carre. Its prognosis is uncertain at this time.

\section{Résumé français}

Le quartier du Vieux-Carré en NouvelleOrléans constitue une attraction exceptionnelle pour les touristes. Cependant, la croissance du volume touristique est telle que cela peut devenir dangereux pour sa survie. La création du "New Orleans Joint Center for Tourism" résulte de l'action de ceux qui veulent conserver le patrimoine historique du Vieux Carré, La mise en commun des ressources d'organismes divers reliés au tourisme démontre la volonté du milieu de contrôler la croissance de l'indusirie touristique et, du même coup, de préserver l'héritage historique du Vieux Carré. Les problèmes que rencontrent le "New Orleans Joint Center for Tourism" pour atteindre ses objectifs relèvent, entre autres, d'un manque de ressources de la direction centrale et du peu d'implication du gouvernement municipal.

Jane S. Brooks, College of Urban and Public Affairs. University of New Orleans. Dr. Kenneth J. Lacho, Department of Management, University of New Orleans.
Introduction

Tourism has grown from the travels of a privileged few and adventurers to a mass movement of people. Since the end of World War II, tourism has developed intoa large-scale industry (Murphy, 1985). For example, in 1987 there were some 355 million international arrivals in all countries with an economic impact of 150 billion \$, excluding airfares (World Tourism Organization, 1987). U.S. tourism stood as the nation's third largest retail industry in 1987 reaching nearly 300 billion $\$$ in expenditures by American sand foreign visitors (Hunt, 1990). By 1988, leisure travel revenues totaled 313 billion $\$$ - or 6.5 percent of the gross national product (Winans, October 3, 1989).

Tourism has proved itself to be resistant to both international and domestic recessions. Because travel is now considered a priority in most family budgets, and is highly recession resistant, the World Tourism Organization projects that by the year 2000 tourism will become the world's leading industry (Inskeep, 1988).

New Orleans, Louisiana, has benefited from the growth of the tourism industry as well. It is a major industry replacing oil and gas exploration. The 1960's marked the beginning of New Orlean's mass tourist industry. Before 1960 there were approximately 4000 hotel rooms; by 1990 there were 25325 hotel rooms. In 1988 , visitors to New Orleans spent 2.55 billion \$ up from $\$ 1.99$ billion in 1984 . There were 47536 persons employed in 1988 in the New Orleans tourist/travel business compared to 37810 in 1984 (Katz, 1990).

During the 1970's New Orleans developed into adestination trip for many conventions. Convention facilities such as the Rivergate and Louisiana Superdome were built as well as four major convention hotels. In 1984 the New Orleans Convention Center was completed with 381000 square feet of exhibit space. This will be expanded to over 700000 by 1991 and 1000000 by 1995 (Riverfront 2000).

One of the main attractions of New Orleans is its multi-faceted culture which made it an international tourist attraction. It provides a mixture of food, music, architecture, history, and arts not readily found in the U.S.. Theattraction to New Orleans reflects the growth in cultural tourism in the United States. This form of tourism according to Roddewig (1988) includes the enjoyment of a location's "heritage - history and architecture; landscape - urban and rural including its wildlife; arts - music, painting, sculpture, literature; sports; cooking and cuisine; leisure time activities; language; local customs; and, institutions". In other words, cultural tourists seek to experience other ways of life from that of their own.

The interest of tourists in the heritage of a destination, in particular, its history and architecture, has become a trend in itself, On the national level, Roddewig (1988) projects that "those states that protect and develop their historic sites will be the leaders in American tourism in the 21st century... Studies from around the country are beginning to show that historic sites and buildings are among the one or two most important attractions to tourists and travelers. Historic sites are now more important than recreational assets as a tourism draw." (1988: 3)

While New Orleans has many cultural attractions such as food, music, Mardi Gras, history, and architecture, which draw visitors, studies show that the Vieux Carre is the region's principal attraction. It is a 258 acre neighborhood in the heart of New Orleans. Much of it survivesas it was in the mid-nineteenth century, reflecting the multiplicity of styles, cultures and historical periods of the past. Some 5000 people live and work there, one of the most historic districts in the United States (Peckham, 1989).

The growth of the New Orleans tourism industry reflects the city's draw as a cultural attraction as well as a "party town", especially for conventioneers. Development pressures caused by the latter segment of the tourism industry have had a negative impact on the ambiance and architecture of the Vieux Carre - a fragile neighborhood (Baumbach, Jr., Brooks, Elstrott, Jr., and Masson, 1988). The real or perceived 
negative impact of tourism on the Vieux Carre - a major tourism strength, and a way of life for many - prompted a meeting of concerned New Orleans citizens in 1986 to determine what actions could be taken. Theresult of these meetings was the decision to hold a symposium in March, 1988 on the management of cultural tourism, entitled Selling the City... Without Selling Out. The group, The Committee for Cultural Resource Development received a Critical Issues Grant from the National Trust for Historic Preservation. The primary objectives of the symposium included: (1) to bring together local, national and international experts to develop a model comprehensive regional plan to manage increased tourism, without harming cultural resources such as the Vieux Carre, and (2) to develop ways for cooperation between cultural groups and the tourism industry (Peckham, 1989).

One of the outcomes of the symposium was the creation of the Joint Center for Tourism (JCT). Its purpose is to serve as a link between the planning, business and architecture units of local universities and to bring together politicians, preservationists, business and tourism representatives for frank discussions on how to build tourism without doing irreparable harm to the historic neighborhoods of New Orleans, especially the Vieux Carre.

The purpose of this paper is to examine the use of coalitions under the JCT and its effectiveness in influencing policy for expanding the city's cultural tourism industry.

\section{Creation of the JCT}

The Joint Center for Tourism was established in January 1989 as a cooperative effort between several academic units at the University of New Orleans (UNO) and Tulane University. Specifically, the College of Urban and Public Affairs and Louisiana Urban Technical Assistance Center at UNO and Tulane University's School of Architecture, Gallier House Museum, and A.B. Freeman School of Business signed the agreement formally establishing the JCT. This agreement marked the first formal cooperative venture by UNO as the major public institution in New Orleans (a member of the Louisiana State University System) and Tulane as the city's major private university.

The JCT was seen as a community based endeavor and participation was encouraged from those individuals and groups who had participated in the symposium. Other groups who participated in the JCT at its founding included the Preservation Resource Center of New Orleans, Le Petit Theatre, Greater New Orleans Tourist and Convention Commission, Bureau of Governmental Research, City of New Orleans, City Planning Commission, and Vieux Carre Commission.

The work of the JCT has been carried out by volunteers. Funds from symposium attendance foes and matching funds for the National Trust grant were used to continue follow-up programs to the symposium. Individuals from the two universities provided necessary staffing for the JCT as part of their public service commitment. The JCT was housed at Gallier House Museum in the Vieux Carre because it provided both a central location between the two university campusesand an historic architectural and cultural image for the organization. Gallier House Museum also operates with some autonomy from Tulane University with regard to accounting procedures. Staff of Gallier House have provided numerous services to the JCT with regard to preparation and distribution of mailings and answering inquiries about JCT activities.

\section{Three Year Goals of the JCT}

As a result of ideas expessed in the final session of the symposium, a list of goals was established. These included the areas of research/policy development, education, coordination and planning, and administration. The major objective of the research/policy development area was to gather data on existing cultural attractions. within the New Orleans Metropolitan Area, including their volume of business, their pricing structure, and client base. Information was to be sought from other successful cultural tourism markets on methods of enhancing existing attractions and developing new ones. A complete goals statement is found in Table 1.

Goals within the education area included facilitating publication of a cultural directory, developing media projects to educate the community on the importance of cultural resources and tourism, and raising public awareness on the fragility of historic resources.

The coordination and planning objectives focused on providing leadership and expertise in cultural tourism planning and managementat the city and state levels. An additional goal was to act as a clearing house for information and ideas which might have application in the New Orleans market.
Administrative goals of the JCT consisted of raising funds for the initial three-year operation with plans for longer-term financing. The need for an advisory board and paid staff was also identified.

\section{Accomplishment of Goals by JCT}

The JCT is now in its second year of operation. The goals program has been revised substantially due to the inability to attain adequate "start-up" funding. However, some objectives within each of the goals areas have been met.

The most notable work has been done in education and community awareness. A community-wide forum was held in May, 1988 to follow-up on the ideas expressed by participants in the symposium. This set the stage for a 90 -minute television show produced on September 19, 1988 on public television station WLAE-TV. Alsoentitled Selling The City... Without Selling Out, the program included a live panel discussion with Councilman Mike Early (representing the Vieux Carre); Ron Jones, President of Louisiana Coca-Cola Bottling Company (representing the New Orleans Business Council); Allan Katz, columnist for the Times-Picayune; Frank Keevers, former Executive Director of the New Orleans Exhibition Hall Authority; Cornelius Lewis, the Governor's Assistant Chief of Staff for Economic Development; and Ann Masson, Director of Gallier House Museum (representing the JCT). The program included taped highlights of the symposium, a screening of the documentary Life and Times of the Vieux Carre, and discussion with an invited audience of community and tourism leaders.

The work done by the JCT was influential in directing the programs of the Greater New Orleans Tourist and Convention Commission (GNOTCC) towards the area of cultural tourism. The JCT co-sponsored a GNOTCC summer tourism roundtable on the subject of cultural tourism. In 1989 , GNOTCC chose the topic of cultural tourism as the theme for their annual meeting.

At the state level, the 1988 Louisiana Governor's Conference on Tourism held in November in Baton Rouge included a major track on cultural tourism. This was the direct result of contacts and information provided by the JCT to the State Office of Tourism. The JCT was requested by the State Tourism Office to be a New Orleans liaison for the Open House 1990 state tourism marketing program.

In the area of data collection and research, some progress has been made on the stated 
TABLE 1

Joint Center for Tourism Research, Education and Planning Three year goals

Research/policy development

Gather product data about all cultural attractions

- Complete cultural inventory undertaken by the Culture, Community and Tourism Partnership, UNO Metropolitan Council for Lifelong Learning

Survey all attractions for additional information about volume of

business, seasonality, pricing structure, perceived client base, etc.

Broaden inventory to include surrounding parishes

Gather performance data

Facilitate completion of the advertising conversion study undertaken by the Greater New Orleans Marketing Committee

Develop model for measuring the economic impact of cultural tourism

Develop system for collecting performance data on an on-going basis

Utilize student and university assistance through $\$ 1000$ support grants

Research tourist access to information and facilities

Gather data on the utilization of cultural resources in other places

Explore methods of enhancing existing attractions and developing new ones

Develop menu of cultural tourism projects

Research zoning and other control mechanisms

Research types of community planning processes used for tourism management

Research tourism funding mechanisms

Develop a community process for the creation of acomprehensive tourism plan that encompasses the heritage corridor from New Orleans to Lafayette

Education

Facilitate the publication of a simple and useful cultural directory at low cost

Educate the community to the importance of cultural resources and tourism

Develop media projects that present the city's cultural assets

Create awareness of the importance of cultural resources

among the city's civic, business and political leaders

Work with the tourism industry for greater utilization of cultural attractions

Educate residents about the importance of visitors to the economy

Circulate mission and goals, create involvement and enthusiasm

Direct visitor attention to resources outside the Vieux Carre

Work with school curriculum personnel to create heritage programs in local schools

Education continued

Raise public awareness of the fragility of historic resources

. Encourage the enforcement of existing laws

- Determine role of the Vieux Carre in New Orleans' tourism

- Investigate potential negative impact of tourism in the Vieux Carre

- Monitor state and federal actions which impact historic resources

Sponsor events
Co-sponsor summer tourism roundtable with the GNOTCC
Produce 90-minute special on cultural tourism with WLAE
Develop program on the potential of international tourism
Hold symposium in March 1989

Co-ordination and planning

Act as a clearing house for information

Offer verbal referrals to those working on similar projects or toward similar goals Produce a simple newsletter about activities and opportunities in cultural tourism Suggest national and international programs which may serve as models

Provide leadership and expertise in cultural tourism planning and management

- Act as liaison with other groups, including city government

Promote citizen involvement in tourism planning:

hold meetings among various groups and organizations as necessary

- Create process for identification of marketing image

Administrative

Establish 25-member advisory board

Raise funds for first year of operation

Plan for long-term financing of the Joint Center for Cultural Tourism

Hire staff and establish procedures

Allocate funds and responsibilities among participants goals. The JCT has worked to coordinate publication and distribution of a cultural resources directory. This directory was the product of a previous coalition. Data for the directory was collected by UNO students in the School of Hotel, Restaurant, and Tourism Management. The data was computerized by UNO's Metropolitan Council for Lifelong Learning. Funding is currently being sollicited for publication of the document.

A contract was negotiated between the JCT and GNOTCC for major data collection on visitor satisfaction levels using hotel and airline exit interviews. However, funding for this contract was contingent upon passage of a tourism tax put before New Orleans voters in March, 1990. This tax included an additional property tax millage along with an increase in the hotel room tax. Unfortunately, the referendum was defeated and the contract was placed on hold.

Administration continues to be a problem area for the JCT. While there is still community-wide support for JCTsponsored activities, a stable financial source has not been forthcoming. JCT programs continue to be staffed solely by volunteers which has slowed progress significantly. However, a small spin-off effort is underway with creation of a Vieux Carre Cultural Attractions Marketing Group. This group was formed by the JCT in January, 1990 and is known as the Cultural Treasures of New Orleans.

\section{Cultural Treasures of New Orleans}

In spite of the great variety of facilities and governing bodies, all Vieux Carre cultural attractions share a common historical base and a desire to educate visitors. Given this common bond, there are many opportunities for cooperative marketing ranging from the most simple to the ultimate step of joint ticketing and advertising. The purpose of this group is to explore the range of joint marketing opportunities and todiscuss ways in which cooperative efforts will work best for all. A list of the participating Vieux Carre cultural attractions is presented in Table 2. Theseattractions includemuseums, Le Petit Theatre, the French Market Corporation (a city agency), and the GNOTCC.

Since January, 1990, the Cultural Treasures group has developed a list of marketing goals (presented in Table 3). Several of these goals have already been metincluding joint distribution of brochures and a systematic program of educating docents at each attraction about the features of the others. 
A more ambitious cooperative project has been the opening of a center for distribution of all brochures on Jackson Square. Le Petit Theatre has offered a portion of its lobby for this purpose. Volunteers to staff the cultural information center are provided by the participating cultural attractions.

Longer term goals of the Cultural Treasures group include working with hotels for displays and in-house cultural attraction T.V.spots, and joint ticketing and promotion of cultural attractions. Ultimately, the idea is tocreate a theme for the cultural attractions as a group and to market it as a new product within the New Orleans tourism market. All parties would agree to aspecific program and packaging concept. Each would contribute to a central fund for promotion and participate in promotional activities (such as joint ticketing and programs). Common marketing decisions would be handled by a steering committee selected by the groupat large. Each attraction would give up some measure of control in order to reap the benefits for the cooperative efforts as a whole.

\section{Local Political and Economic Environment During JCT's Formation}

The formation of a coalition to hold the 1988 symposium and the subsequent establishment of the JCT needs to be considered in light of the changing economic conditions in New Orleans during the 1980 's. The economy of the area was severely depressed due to the decline in the oil industry. Tourism emerged as a major force in the economy of the metropolitan area. New Orleans was being positioned, intentionally or not, as a "party town". Also, the city was going from event to event, e.g., superbowls, the Pope"s visit, NCAA Final Fours, the 1988 Republican Convention, annual events such as Mardi Gras and conventions large and small. The major thrust of the Greater New Orleans Tourist and Convention Commission was that of getting convention business. In addition, the 1984 World's Fair had the impact of additional hotel rooms being built as well as the building of the New Orleans Convention Center. Touristattractionssuch as a first-class aquarium and riverfront development were also on the horizon.

Studies have documented a large increase in tourists visiting New Orleans. In 1985 , 4.9 million tourists came to the city up from 1.8 million in 1965. This extraordinary increase in the last twenty years has created serious problems for the Vieux Carre. These problems are reflected in two important areas: land use change and regulations. As

\begin{tabular}{|c|c|c|}
\hline & \multicolumn{2}{|c|}{ TABLE 2} \\
\hline \multicolumn{3}{|c|}{$\begin{array}{l}\text { Participating organizations in the cultural } \\
\text { treasures of New Orleans subgroup }\end{array}$} \\
\hline Organization & Type & Orientation \\
\hline Beauregard-Keyes House & Museum & Preservation \\
\hline French Market Corporation & Government & Tourism \\
\hline French Quarter Festival & Event & Tourism \\
\hline Gallier House Museum & Museum & Preservation \\
\hline GNOTCC & Trade Association & Tourism \\
\hline & Museum & Preservation \\
\hline $\begin{array}{l}\text { Hermann-Grima House } \\
\text { Historic New Orleans Collection }\end{array}$ & Museum & Preservation \\
\hline \multirow{2}{*}{$\begin{array}{l}\text { Le Petit Theatre } \\
\text { Louisiana State Museum }\end{array}$} & Arts & Preservation \\
\hline & Museum & Preservation \\
\hline $\begin{array}{l}\text { Louisiana Urban } \\
\text { Technical Assistance Center }\end{array}$ & University & Preservation \\
\hline Musee Conti & For Profit Museum & Tourism \\
\hline \multirow{2}{*}{$\begin{array}{l}\text { N.O. Pharmacy Museum } \\
\text { Tulane University Freeman }\end{array}$} & Museum & Preservation \\
\hline & & Tourism/Econ. \\
\hline \multirow{2}{*}{$\begin{array}{l}\text { School of Business } \\
\text { UNO College of Urban \& }\end{array}$} & University & Development \\
\hline & & \\
\hline Public Affairs & University & Preservation \\
\hline
\end{tabular}

Murphy (1985) pointed out in Tourism: $A$ Total Community Approach: "The physical deterioration of the environment, whether it be in a national park setting or seaside resort [or historic district] is due in the main to an imbalance between tourist demand and physical carrying capacity of a destination area. Under these circumstances, the expected symbiotic relationships between tourism and conservation break down and conflict develops (1985: 60)".

Such is the case in the Vieux Carre where the developmental pressures of increased tourism have resulted in the loss of neighborhood quality. Population has declined from 10000 residents in 1950 to 5000 in 1980 (Wagner and Nebel, 1984). A major change in the socio-economic profile of these residents has also occurred with a shift from moderate income families, often with strong traditional ethnic ties, to higher income professionals, either single or couples without children. A large gay community has also developed.

With this change in the neighborhood residential profile has come a replacement of neighborhood businesses by those specifically related to tourism. A 229 percent increase in tourism-related shops was noted between 1961 and 1981 (Coote, 1982) with 110 of those businessesclassified as T-shirt shops. The rapid rise of property values and taxes for buildings in the historic district has contributed to this residential displacement problem and has made high- quality renovation more difficult to achieve (Baumbach et al., 1988).

The traditional land use of the Vieux Carre riverfront has changed dramatically in the last decade from predominantly industrial use to tourism-related activities. This change has created conflicts over the appropriate scale and density of these new festival market place retail facilities and their accoompanying parking needs. While developers and city agencies have viewed this transition or rebirth of the riverfront as apositive economic infusion into the tourism industry locally, Vieux Carre residents and business interests have become concemed over the increased commercialization of the riverfront and its accompanying traffic problems affecting the Quarter as a hole (Baumbach et al,, 1988).

In light of changing and threatening conditions, four persons seem to have been key actors in establishing the initial coalition. Three of the four can be considered to be strong preservationists, i.e., having a very high concern in preserving the unique character of the Vieux Carre. The fourth had a tengential interest in preservation, however, his main orientation could beconsidered to be toward economic development (tourism). The primary concern of the preservationists was the impact of tourism on the Vieux Carre. 


\section{TABLE 3}

\section{Cooperative marketing strategies for}

Vieux CarreCultural attractions

\section{1- Basic level of cooperation}

A- Distribute one another's brochure consistently.

B- Educate docents at each attraction about the features of the others. Promote one another more systematically - word of mouth is important for each of us.

C- Create a master mailing list, handled by a neutral party, which would enable us to more economically reach our established markets.

\section{II- Mid-level cooperative projects}

A- Open a center for distribution of all brochures. Don Marshall offered the comer of the Le Petit Theatre lobby near Jackson Square. Every institution would supply its own materials, including information about daily and special events. Volunteers would be necessary to staff the desk.

B- Cultural display boards could be placed at the Le Petit desk and at other points around the Vieux Carre. These would contain permanent descriptions of attractions and highlight special events.

C- Create signage in the VC that would direct visitors to cultural spots.

D- Utilize display windows in the hotels.

E- Create a display for use at trade shows and within the industry.

F- Cross-promote by offering discounts to one another's facilities, reference to the "Best of New Orleans" brochure.

\section{III- Ultimate level of cooperation}

A- Elements of an Ultimate Cooperative Marketing Plan

1- Define product.

The development of a successful product requires decisions concerning theme, positioning, buyer perception, target markets, etc.

2- Create mission statement for produet. What is the product intended to accomplish for each attraction?

3- Create a name, symbol and logo.

4- Define opportunities to market through tour operators, travel agents, ground transportation, hotels, etc. and plan for these.

5- Decide on structure and budget, locate funding.

6- Begin packaging process.

Decide on specifics such as number and kind of promotions and advertisements.

7- Create mechanisms to track effectiveness.

8- Perhaps move on to include attractions outside the VC and package a family/cultural tour including plantations, etc.

B- General comments

1- Need to start small, without much expense, and to build toward more sophisticated plans.

2. If this is as successful as it seems it might be, there may be no need to discount admissions.

3- Reminder of the need for family attractions, which we all are.

4- Provide avenues to introduce tourists and residents to the depth of culture in VC.

\section{IV-Specific products}

A- Create a cultural page/column/brochure for GNOTCC materials and/or mailings. Write stories for them to carry. Perhaps pay for a cultural brochure to be included with their materials.

B- Sponsor the production of a short, professionally-produced video for showing on VTV, by the GNOTCC, etc.

C- Create and promote special events, such as an historical week-end in the Vieux Carre.

D- Seck participation in summer promotion coupon books, hotel coupon programs, LTPA materials, etc.

E- Have banners produced (seek a specific sponsor) that would signify an attraction's participation in a network of cultural properties.

\section{Evaluation of JCT Efforts}

Organizations often form coalitions or collaborate to gain control over an uncertain environment(Cyert March, 1963). In many cases an organization cannot bring about the change it desires alone as it lacks the necessary power. To reach its objectives it gets allies (Newman, Logan, and Hegarty, 1989). Firms or organizations pool resources, exchange resources, or follow other ways of cooperating to achieve mutual ends. A classic example is that of Ocean Spray Cranberries, Inc., formed in 1930 by independent and competing cranberry farmers. By pooling their resources and marketing through a cooperative, the industry expanded primary demand (Nielsen, 1988).

In the case of the JCT, the initial coalition membersattempted to gain control over the environment by widening membership to include groups or organizations interested in economic development, especially tourism. Such groups as those cited above were strongly persuaded to join the symposium and then become members of the JCT. The primary argument for joining the JCT was that cultural tourism was a growing influence in the U.S. for travel.

As indicated above, the JCT has not progressed very far since its formation. Why not? Several reasons are suggested. First, there were too many organizations or actors involved, especially those persons from organizations concerned with the development of tourism. More importantly, was the lack of resources, people andmoney. All persons involved were on a volunteer basis and had full-time jobs which perhaps were more than usually demanding on their time given tough business conditions. Secondly, the lack of money was a severe limiting factor. Though a small grant was received from the National Trust for Historic Preservation, it did not go far enough. The lack of funds prevented the hiring of a fulltime executive director to direct and coordinate the center's efforts. In addition, funds were lacking for a large-scale effort to promote cultural tourism, conduct research, and achieve many of the objectives stated in the JCT's charter. The second grant request to the National Trust, a possible source of funds was denied. Little financial support was forthcoming from the City of New Orleans and the Greater New Orleans Tourist and Convention Commission because of their own financial weaknesses. Another source of potential funding was denied when voters refused on March 3, 1990 to pass a tax dedicated to promoting tourism for New Orleans. In addition, the time demands of business and civic leaders during this period were increased by the 
(suile de la page 5)

beaucoup et on bétonne de vastes espaces. Des vacances étalées sur une base plus large permettraient de repondre aux besoins d'un plus grand nombre de vacanciers avec moins d'équipementseten protégeant donc mieux $l^{*}$ espace naturel de la station. Mais si les touristes avaient plus de latitude pour choisir le moment de leurs vacances, il n'est pas dit qu'ils en feraient un meilleur étalement. Cette question devra être traitée conjointement avec celle des vacances scolaires.

La concentration des équipements récréotouristiques dans l'espace est un sujet plus controversé. Les auteurs consultés estiment qu'un bon moyen de protéger les milieux naturels fragiles en zone touristique est de concentrer les équipementset services. Par exemple, un hôtel de centchambresconstruit sur un terrain de deux acres agressera moins l'environnement que cent résidences secondaires construites sur les rives d'un lac sur des terrains "aménagés" d'un acre chacun. Mais ce ne sont pas tous les aménagistes, ni tous les urbanistes, ni tous les ćcologistes qui partagent cette approche, qui $n^{7}$ estd'ailleurs pas sans nous faire penser à des politiques gouvernementales ou à des approches de devveloppement discutées sérieusement à haut niveau. Par exemple, quand on a institué, il y a une quinzaine d'années, le programme du Crédit touristique, on avait limité son application à des portions de territoire bien délimitées en fonction de la qualité du potentiel touristique sur les plans régional, national ou international, La loi 37 identifiait donc des portions de territoire comme station touristique, comme pôle touristique, comme corridor touristique, etc, et les ressources du Crédit touristique n'étaient admissibles qu'à 1'intérieur de ces espaces. Voilà un moyen de concentrer et d'intégrer les différents produits touristiques... et sans doute de protéger l'environnement.

Plus près de nous, à l'arrivée en fonction du ministre André Vallerand et de son sousministre Michel Roy, on avait commencé à aviser les Associations Touristiques Régionales (ATR) que $\mathrm{l}^{\text {*intention }}$ gouvernementalétaitd d'appuyer davantage les régions disposant d'importantes ressources récréo-touristiques tout en réduisant l'appui aux régions moins bien pourvues. On a laissé tomber cette approche parce qu'elle n'était pas "électoralement rentable". Car, au pays du Québec, c"est bien souvent la rentabilité politique qui détermine ce qui est bien et ce qui est mal. Et cela n'est pas propre au Québec...

\section{Notes explicatives}

11) KFIPPENDORF, Jost (1977), Les dévoreurs de paysages - Le tourisme doit-il détruire lessites quil le font viure? Editions 24 heures, Lausanne. 1. 88

(2) ROY, Jean-Hugues (1990), "Pas devacances pour Femironnement - La tourista ronge la planete". revue Écologie, Montréal, p. 8

3) KRIPPENDOFF Jost 11977 , lbid, D. 56

4) OMT (1980) Etude sur la contribution du tourisme a la protection de l'environnement. Rapport del'Assemblese genéraledel'Organisation mondiale du tourisme, New Delhi, pp. 10-11

(5) DORST, Jean (1970). La nature denaturée. Editions Delachaux \& Niestle, Collection "Points", no 9, 192 pages.

(6) KRIPPENDORF, Jost (1977), lbid, p. 17

(7) OMT (1993) lbid p. 10

(B) NADEAU, Roger (1963), "Le milieu naturel québeoois, "e'est beau engrand" ", revue Téoros, wol. 2, no 2, UQAM, Montreal. UApouyé par I'ouvrage de KALAORA, Bernard (1981), Le musée vert- oule tourisme en forät, Editions Anthropos, Paris.

(9) OCDE (1980). L'Impact du tourisme sur Fenvironnement. Rapport géneral de IOrganisation de cooperationet dedeveloppement economique, Paris, p. 41

(10) OMT (19B3), lbid, p. 2

(11) NADEAU, Roger (1909), "Le recreo-tounisme en Estrie: un apport positif à la gestion de "environnement", Le recréo-tourisme: une nouvalle voie dé dóvaloppement. Association professioninelle des géographes du Quebec APGGOI at Module de gégraphie de l'Universite du Québec à Chicoutimi, sous la direction de JuanLuis Kein et Bemard Maltais, Chicoutimi, pp. 123 134

(12) KAIPPENDORF, Jest 11977), Ibid, PP. 90 et 47

(13) CANADA (1990), Le tourisme, un pas à franchir, Industrie, Sciences et Technologie Canada. Ottawa, pp. 21-22

114] Quebec (1990). Enonoé de politique en matlère de tourisme. Document de réflexion. Gowvernement du Quebec, ministere du Tourisme. Québec, p. 40

(suite de la page 25)

pressure of other problems related to the city, e.g., education, saving local art groups such as the symphony, fiscal reform and the March 3 rd tax proposal.

Another way of analyzing the JCT's situation is to view it as a conjugate collective (Astley and Fombrun, 1983). Such collectives are those in which members from different sectors of the same industry (e.g., preservationists, and tourism-related firms) are related to each other, respectively, in term of their inputs and outputs (Evan, 1966). Interindustry collaboration in conjugate collections relies quite a bit on legal sanction and formal agreement as control mechanisms (Astley and Fombrun, 1983). In the case of the JCT there were no such control mechanisms. Of the two universities involved, one hesitated to sign an agreement reflecting the joint partnership of these two universities in the JCT.

In summary at this point, the progress of the JCT has primarily been thwarted by a lack of resources and formalization of an agreement. On the other hand, a subgroup of preservation-oriented individuals has evolved.

\section{Formation of the Cultural Treasures Subgroup}

An interesting spinoff of the JCT is the formation of another coalition as described above. Although it is too early to evaluate the subgroup's success in achieving its objectives, several observations are in order. For one, the membership reflects a strong interest in preserving the Vieux Carre, improving site (museum) and event visitations. Two of the key leaders are strong preservationists. Collectivelly, this group desires to create a stronger force in dealing with the City of New Orleans governmentso problems of the Vieux Carre such as litter, the homeless, and crime can be addressed. This would make the Vieux Carre a more livable place for residents and an interesting attraction for tourists. In contrast to the JCT, the subgroup is more cohesive. Members possess similarvalues, especially in preserving the Vieux Carre. On the other hand, the spinoff group has a problem similar to that of the JCT, a lack of resources, especially money.

A review of the cooperative marketing strategiesdeveloped by this group (see Table 3) suggests several concerns. As in the case of the JCT, all members are on a volunteer basis. Secondly, many of the marketing effortse.g, signage, window displays, tradeshow displays, video production, and brochures, will cost money unless tradeouts can be arranged with suppliers of such services. Lastly, no provision is being made for a full-time director, one who can coordinate the efforts of coalition members.

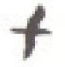

Bibliography

ASTLEY, W.G. and FOMBRUN, C.J. (1983), Collective Strategy: Social Ecology of Organizational Environments, Acadomy of Mana gement Review, B (4), $576-587$

BAUMBACH, Ir. R.O., BROOKS, J.S., ELSTROTT, Ir J.B. and A.M. MASSON (1989), Issuas and Opportunities in Cultural Tourism, Unpublished report to the National Trust for Historic Preservation

coOTE, EA. (1982). The Vieux Carre: 1961 to 1981 . New Orleans, LA, Loyola University, College of Business Administration.

CYERT, R,M and MARCH, J G. [1963). A Behavioral Theory of the Firm, Englewood Cliffs, NJ. PrenticeHall Ind

EVAN W (1966). The Organizations - SeL Toward a Theory of Interorganizational Relations, in $J . \mathrm{D}$ THOMPSON led.I. Approaches to Organizational Design, Pittsburgh. University of Pinsurgh Press, 175-190.

HUNT, J.D. (1990), State Tourism Ofrices and theit Impact on Tourst Expenditures, Jeurnal of Travel Research, 25 (3), 10-13

INSKEEP, E. (1968). Towism Planning An Emerging Specialization. Journal of the American Planning Association, 54 6937, 360-372

KATZ,A. (1990, January 151. How New Oreans Achieved a Reputwion? as a Big Event Town, City Business, pp $21-23$

MURPHY, P.E. (1985), Tourism: A Community Approach. New York, NY, Wethuen Inc.

NEWMAN, WH LOGAN, IP and WH HEGARTY [1989). Strategy: A Multi-Level Integrative Approach, Cincinatt, $\mathrm{OH}_{4}$ South-Westem Publishing Co.

NIELSEN, R.P. (1988), Cooperative Strategy, Strategic Management Journal, 9, pp. 475-492

PECKHAM, PG 11989. Cultural Tourism in New Orleans: A Case Study of Tourism Planning and Management Strategies, unpublished Master's thesis, University of New Orleans, New Orleans, LA. RODDEWIG, R.J. (1980), Selling Amenica's Heritage. Whout Selling Out, Preservation Forum, 2 (3), pp 2-7

WINANS, C. (October 3. 1989). For U.5. Tourism the Holiday may be Over. Wall Street Journal, B 16.

WAGNER, F and NEBEL, E (1984), Facing Change In the Vleux Carro, New Orleans, LA, University of New Orleans, School of Urban and Regional Studies and School of Hotel, Restaurant and Tourism Maracement 